\title{
Taxation an Effective Tool for Income Re-Distribution in Nigeria
}

\section{Osasu Obaretin}

ACA, ACTI, Ph.D, University of Benin,

Faculty of Management Sciences,

Department of Accounting;

Sadiq Oshoke Akhor

ACA, ACTI, MSc, Bursary Department, College of Education, Igueben

\section{Osahon Emmanuel Oseghale}

\author{
ACA,ACE,MBA, First Bank Limited
} Ozoro, Delta State

Doi: $10.1515 / m j s s-2017-0017$

\section{Abstract}

This paper focused on taxation as a tool for effective income re-distribution in Nigeria. To achieve this data for the study were gathered from secondary source which include the Office of the Federal Inland Revenue Service and the World Bank Data Bank for the relevant years 1981 to 2014 (34 years) and this period is consider long enough to eliminate any effect of short run fluctuation on the dynamic on taxation and income redistribution in Nigeria. However, the ordinary least square statistical tool was used in analysing the time series data gathered. From the analyses the paper concluded that all tax variants do not exert significant impact on income disparity as observed by GINI at 5\% level. The result suggests the taxation as not be able to fulfil its role as a standard tool of income re-distribution in Nigeria. Premised on the conclusion the paper recommended that the there is the need for effective, and equitable utilization of tax revenue and this recommendation suffices because of the insignificant influence of taxes on the level of income inequality as measured Gini-coefficient. Thus, the paper proposes that that there is the need to examine properly the distributional impact of the Nigerian tax system to (or "intending to") ensuring that taxes create a more income-inclusive society by bridging the income disparity gap between the poor people and the rich.

Keywords: direct tax, indirect tax, income disparity, regression

\section{Introduction}

The survival of any country relies on upon the measure of resources that are available for the provision of security, basic infrastructure and to meet her recurrent and capital expenditure. There appears to be a consensus that Nigerian economy is overly dependent on revenue from petroleum products, with oil representing more than $70 \%$ of the aggregate government total revenue. Premised on the above assertion and in the face of the dwindling global price of crude oil, it becomes of necessity for Nigeria government to seek and maintain an alternative and reliable source of revenue. To this end, the importance of tax revenue has as vital source of government revenue cannot be overemphasised. Tax as indicated by Eiya (2012), is a levy compulsory imposed on the income, profit and capital gains of the individual, organisations or other legitimate elements 
by the government to raise revenue. Tax is a compulsory transfer or payment from private people, organizations or groups to the administration (Anyanwu, 1997). While Anyaduba (1999), described tax as a mandatory levy imposed by a public authority on the profit, income or wealth of an individual, family, group, corporate or unincorporated body for public purpose. Notwithstanding, (Bhartia, 2009; Ola, 2001) opined that the major reason for the imposition of tax is to raise revenue to meet government uses, to redistribute income and the administration of a country economy

However, the primary motive for the imposition of taxes is to meet the expenditure of government and effectively redistribute income which thus will converts into economic growth and development of a country ( Bhartia, 2009; Jhingan, 2004; Ola, 2001; Musgrave and Musgrave, 2004; as cited to by Worlu and Emeka, 2012). Taxation as a fiscal tool could be used to enhance a nation's development process and its economic activities, thereby improving the overall level of prosperity and economic well-being of the entire citizenry (Anyaduba, 1999).

Tax is a major administrative pivot of any society (Azubika, 2009). With tax system serving as an avenue for government to gather income required in releasing its social commitments. Tax framework offer itself as a foremost means of mobilising a country's resources in an efficient and effective manner and thereby making a situation favourable to economic growth and development (Akintoye and Tashie, 2013). They additionally accentuated that taxes furnish the government with the means to provide security, social amenities as well as creating a situation for an enhanced economic welfare of a state. On the other hand, Odusola, (2006) asserted that Nigeria revenue has been to a great extent gotten from essential item, expressing that in the between 1960 and the mid 1970s, income from agricultural items dominated while income from other sources were not given most extreme consideration, since the oil boom of the 1971 to the $77 \mathrm{~s}$, oil revenue has dominated the Nigeria's income and its share of the governmentally gathered income ascended from 26.3 percent in the 70 s to around 70 percent up to mid 2014. Thus signifying that conventional taxes have never assumed a significant role in the nation's administration of its fiscal policy. Because of the over-reliance on crude oil, Nigeria economy has been subjected to the fluctuations of the international oil market (Akintoye and Tashie, 2013).

This paper is motivated by the need to reveal more insight into the role of taxation as a tool for income redistribution particularly in Nigeria and to evaluate the extent to which that role has been effectively carried out.

\subsection{Hypothesis of the Study}

For the purpose of this study the hypothesis is stated in the null (Ho) form and is so stated as; tax revenue has no significant effect on income inequality in Nigeria

Closing following the introduction is section two which is on review of literature while three is on the methodology; section four is on the conclusion and recommendations.

\section{Review of Literature}

In this section a careful and a painstaking review are carried out on the concept of taxation, taxes, income redistribution otherwise refer to income inequality and the relationship between tax revenue and income redistribution was also carried out.

\subsection{The Concept of Taxation and Tax}

Taxation is a tool for societal development and also a means by which the rewards of development are redistributed (Oladiran, 2009). The historical backdrop of both advanced and developing nations uncovers that taxation is a critical instrument in the hands of the government, not only to generate revenue but also to achieve fiscal goals such as influencing the direction of societal development. According to New Internationalist magazine (2008), tax originated from the Latin word 'Taxare' which means 'to assess'. While Ariwodola (2008) describes taxation as a method by which a nations implements decisions to transfer resources from the private to the public sector. 
Adejuwon (200) describes taxes as levies compulsorily imposed on the income, capital and consumption of the people by the government through its agencies so as to increase the resources of the government and enhance the effective provision of social amenities. Traditionally, taxes are based on income of individuals or profits of an economic entity, (Naiyeju, 1996). Ndekwu (1991) also states that like never before, there is now an increase interest for the improvement of revenue from the different taxes in Nigeria. The call for government in the affairs of man is the basis for taxation. This follows the idea that if there is to be a government to superintend human affairs in a given territory, such a government will need resources (human and material) to achieve its objective. The most efficient way of getting such resources is for individuals in the territory concerned to contribute in an agreed manner; such contribution referred to as tax (Osemeke, 2010).

In the opinion of Anyaduba (2000), tax is a levy compulsorily imposed on the income of individual, household and corporate entity by the government or its agent for the purpose of raising revenue. While Ogbonna and Appah (2012) assert that the main aim of taxation is to raise income to finance government expenditure and to redistribute riches and the management of the economy. In any case, Johansson, Powerful, Arnold, Brys and Vartia (2008) portray tax system as a system that is primarily aimed at financing public expenditure. They emphases the importance of tax revenue as a tool for promoting equality and re-addressing issue of social and economic concerns. Tax is a levy compulsorily imposed on a citizen or upon his or her properties by the state to provide security, social infrastructures and cerate the enabling environment for the economic welfare of the society (Appah, 2004, Appah and Oyandonghan, 2011). They further assert that the tax payable by an individual is not a function of the benefit derivable from the process. The fundamental reason for imposing tax has always been to finance government activities, redistribute income, stimulate economic activities, and influence the level of aggregate demand among others. From the above, tax can be seen as a necessary or an obligatory demand imposed on the income, profit and gains of individual, family unit, firms (joined and unincorporated) by the government with the end goal of raising income to meet State commitments to her nationals. In differentiating taxation from tax, the latter is a compulsory levy imposes on the profit, income and gains of individual, firm and other entity by the agencies of government or the government in other to raise revenue for the government while the former is the system or process put in place by the government or its agencies in raising the needed revenue.

\subsection{Income Re-distribution}

This is an unequal distribution of the income of individual, household over the different participates in an economy. Income disparity is often expressed as the rate of income to rate of the populace. The reasons for income disparity can differ essentially by education, sex, religion and social status. In the perspective of Ilaboya and Ohonba, (2013) income disparity is address through an assortment of public policies, for example, social expenditure and taxation. By social expenditure they emphasised expenditure one education, health sector and housing. In any case, the degree to which taxation has been able to bridge the gap of income disparity has been the focus of prolong debates in the advanced countries of the world.

\subsection{Taxation and Income Inequality}

Ever since the path-breaking work of Kuznets' (1953) that inequality follows an inverted-U shape with economic development, rising in initial stages of industrialisation and declining with subsequent development inequality, the focus on income inequality has increased tremendously. Consequently, there are good economic reasons for emphasis to be given to this subject. Not only does high inequality lead to higher poverty levels at current income levels, but it constitutes a barrier to poverty reduction.

In the study of James and Robert, (2007) on the effect of the structure tax on economic growth and income disparity, data were gathered from 65 countries over a period of 1970 to 2006. The study applied the Ordinary Least Square, random effect and fixed effect estimations. The study 
reveals that statutory corporate income tax rates are negatively correlated with income disparity after taking into consideration other determinants of economic growth and income re-distribution. Be that as it may, the study also showed that personal income tax has no effect on income inequality. On the other hand, the study also found that high company income tax rate of over $40 \%$ correspond with lower income disparity. The review additionally found that company income tax rate lower than $40 \%$ are not significant in reducing income inequality.

Claus, Martinez-Vazquez, and Vulovic, (2012) examined the role of taxation and government expenditures on a combination of companies and personal income are progressive over time and are effective as a tool for income redistribution.

Rodrigo and Ivanna, (2010) examined equity and fiscal policy, focusing on the distributional impact of taxes and social spending of Central America countries and the study revealed that the income distributional effect of taxes are regressive but in an insignificant manner. They further stated that increasing taxes and channelling the revenue to social spending would undoubtedly enhance the income of even the poorest family units.

Chu, Davoodi and Gupta, (2000) examined income distribution, tax and government social spending policies in developing nations, between 1980 to 1990 (20 years),the study revealed that unlike industrialised nations, developing nations have not been able to use taxation and transfer policy to adequately cut down on the issue of income disparity. With strong emphasis that tax proportion and urbanisation were factors statistically relevant and the level of relevance was found to be robust.

However, the study of Saez, (2004) assessed the efficiency and effectiveness of indirect tax and direct tax instrument in term of income redistribution both in term of long run and short run. The work found out that indirect taxes are favour in the short run as a tool for income redistribution in a situation where skills are exogenous and individual taxpayers are constraint from moving from job to job. Also stating that in the long run, it is more reasonable to say that people pick their occupation in view of the relative after-tax benefits. He further concluded that in the long run, direct taxes should be preferred to indirect tax as a tool to raise revenue and to address the issue of income redistribution.

In a similar vein, Weller and Rao, (2008) evaluated the advantages of progressive taxes to economic growth utilising cross country data covering a time of 21 years (from 1981 to 2002). The review uncovered that progressive income tax could lead to higher equitable distribution of income, higher revenue, reduce financial and economic volatility and rapid growth of the economic.

\section{Methodology}

A time series design was used for this study while relevant marco-economic data were obtained from the World Bank data Bank, Central Bank of Nigeria Annual Report, Annual Abstract of statistics from the office of National Bureau of statistics and the tax data were obtained from the Office of the Federal Inland Revenue Service for 34 years (1981 to 2014). Thereafter, the ordinary least square statistical tool was used in analysing the data gathered. The significant level was set at 0.05 level of significance. The dependent variable was income inequality, while the independent variables were direct tax, indirect tax and total tax. The data were further analysed using procedure within the e-views 8 .

\subsection{Model Specification}

In an attempt to examine the effect of Taxes on GINI coefficient measure for income inequality in Nigeria from 1981 to 2014 alongside other control variables, and the below model was used to analyse the hypothesis;

$$
\begin{aligned}
& \text { GINI }=\eta_{0}+\sum_{j=1}^{q} \eta_{2} \Delta T D T_{t-j}+\sum_{j=0}^{q} \eta_{3} \Delta T T R_{t-j} \sum_{j=0}^{q} \eta_{4} \Delta T I T_{t-j}+\sum_{j=0}^{q} \eta_{5} \Delta O P N_{t-j}+\sum_{j=0}^{q} \eta_{6} \Delta F D I_{t-j}+ \\
& \sum_{j=0}^{q} \mathrm{n}_{7} \Delta I N F_{t-j}+\sum_{j=0}^{q} \varphi_{1} \Delta E C M_{t-1}+\varepsilon- \\
& \text { Where: } \\
& \text { TTR }=\text { Total tax revenue }
\end{aligned}
$$




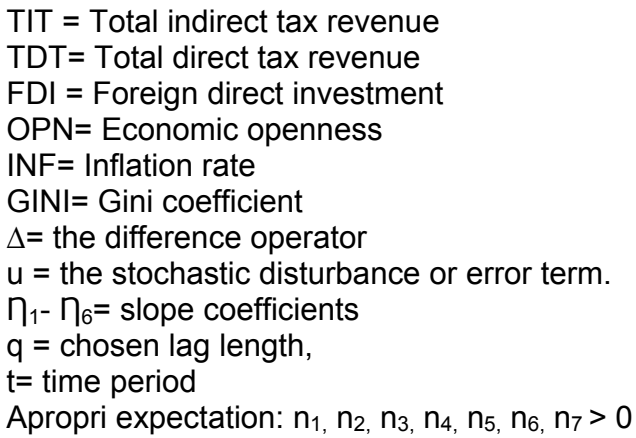

\section{Data Analysis, Interpretation of Result and Discussion of Findings}

This paper has attempted to empirically evaluate the effect of taxes (direct and indirect) on income re-distribution in Nigeria. This section deals with the presentation and analysis of data gathered. The data were however analysis using (a) unit root test, (b) descriptive analysis (c) error correction model

\subsection{Unit Root Test}

Table 1.1: Augmented Dicky-Fuller (ADF) Test Results

\begin{tabular}{|c|c|c|c|}
\hline \multicolumn{5}{|c|}{ Unit Root Tests at Levels } \\
\hline Variables & ADF-Test Statistics & 95\% Critical ADF Values & Remarks \\
\hline TDT & 1.916 & -2.96 & Non-stationary \\
\hline TTR & 0.426 & -2.96 & $"$ \\
\hline TIT & -1.891 & -2.96 & " \\
\hline FDI & -0.285 & -2.96 & Stationary \\
\hline INF & -3.568 & -2.96 & Non-stationary \\
\hline OPN & -2.164 & -2.96 & Non-stationary \\
\hline GINI & -1.011 & -2.96 & Remarks \\
\hline \multicolumn{5}{|c|}{ Unit Root Test at $1^{\text {st }}$ Difference } \\
\hline Variables & ADF-Test Statistics & $95 \%$ Critical ADF Values & Stationary \\
\hline TDT & -6.282 & -2.96 & Stationary \\
\hline TTR & -5.696 & -2.96 & Stationary \\
\hline TIT & -7.088 & -2.96 & Stationary \\
\hline FDI & -4.982 & -2.96 & Stationary \\
\hline INF & -5.880 & -2.96 & Stationary \\
\hline OPN & -4.193 & -2.96 & Stationary \\
\hline GINI & 3.532 & -2.96 &
\end{tabular}

Source: Eviews 8.0 Output (2015).

Table 1.1 presents the consequences of the Augmented Dicky-Fuller (ADF) test in levels without taking into cognisance the pattern of the variables. The rationale for this is premised on the fact that express test of the pattern of the time series data have not be carried out.

In the outcome, the ADF test statistics for the variables is revealed in the second column, while the 95 percent critical ADF values are revealed in the third column of the table. The outcome demonstrates that all the variables at levels have ADF values that is lesser than the value at 95 percent critical $A D F$ value of 2.96. Looking at the variables at levels, the outcome is as per the following; TDT (ADF=-1.916), TTR (ADF=0.426), TIT (ADF=-1.891), FDI (ADF=0.285), INF (ADF=3.568), GINI (ADF=-1.011), OPN (ADF= 2.164). As observed only INF was stationary at levels while others were non stationary at levels. Pushing ahead, we examine the first differences of the 
variables and perform again a unit root test on each one of the resultant time series data. The reason for this procedure as indicated by Box and Jenkins (1976) is that in differentiating nonstationary time series variables would enable us achieve stationarity. Hence, examining the variables at first difference, the result is as follow; TDT (ADF=-6.282), TTR (ADF=-5.696), TIT (ADF=-7.088), FDI (ADF= - 4.982), INF (ADF=-5.880), OPN (ADF=-4.193), GINI (ADF=3.532), The after effect of the unit root test on these variables in first differencing demonstrates that the ADF values in absolute terms are higher than the 95\% critical ADF values. With these outcomes, these variables are declared to be stationary. Hence, we accept the hypothesis that the variables under consideration have unit roots. Without a doubt, the variables are coordinated of order one i.e. I(1).

Table 1.2: Philip Perron Unit Root Test Results

\begin{tabular}{|c|c|c|c|}
\hline \multicolumn{5}{|c|}{ Unit root tests at levels } \\
\hline Variable & ADF-Test Statistic & 95\% Critical ADF Value & Remark \\
\hline TDT & -1.994 & -2.96 & Non-stationary \\
\hline TTR & -0.426 & -2.96 & Non-stationary \\
\hline TIT & -1.891 & -2.96 & Non-stationary \\
\hline FDI & -5.210 & -2.96 & Stationary \\
\hline INF & -2.872 & -2.96 & Stationary \\
\hline OPN & -2.141 & -2.96 & Non-stationary \\
\hline GINI & -1.203 & -2.96 & Non-stationary \\
\hline \multicolumn{5}{|c|}{ Unit root test at $1^{\text {st }}$ difference } \\
\hline Variable & ADF-Test Statistic & $95 \%$ Critical ADF Value & Remark \\
\hline TDT & -7.284 & -2.96 & stationary \\
\hline TTR & -6.615 & -2.96 & Stationary \\
\hline TIT & -7.088 & -2.96 & Stationary \\
\hline FDI & -23.714 & -2.96 & Stationary \\
\hline INF & -9.098 & -2.96 & Stationary \\
\hline OPN & -5.509 & -2.96 & Stationary \\
\hline GINI & -4.345 & -2.96 & Stationary \\
\hline
\end{tabular}

Source: Eviews 8.0 Output (2015)

Table 1.2 presents the consequences of the Phillip-Perron (PP) unit root test at levels and first contrast. Phillips-Perron (PP) (1988) test is an augmentation of the Dickey-Fuller (DF) test, which makes the semi-parametric remedy for autocorrelation and is stronger on account of feebly autocorrelation and heteroscedastic regression residuals. As per Choi (1992), the Phillips-Perron test gives off an impression of being more capable than the ADF test for the total information. Evaluating with intercept, the outcome is as per the following; Examining the variables at levels, the outcome is as per the following; TDT(ADF=-1.994), TTR (ADF= - 0.426), TIT (ADF=-1.891), FDI $(A D F=-5.210)$, INF (ADF=-2.872), OPN (ADF= - 2.141). GINI (ADF= - 1.203). As watched just INF supposedly is stationary at levels while every other variable are non-stationary at levels. Pushing ahead, we take the main contrasts of the individual variables and play out the unit root test on each of the resultant time arrangement. Analyzing the factors at first contrast, the outcome is as per the following; TDT(ADF=-7.284), TTR (ADF=-6.615), TIT (ADF=-7.088), FDI (ADF= - 23.714), INF $(A D F=-9.098) \mathrm{GINI}(A D F=-4.345)$ and OPN (ADF= - 5.509). The consequence of the unit root test on these variables in first differencing demonstrated that the PP values in outright terms are more prominent than the $95 \%$ basic ADF values. With these outcomes, these variables are decreed to be stationary. In this way, we acknowledge the hypothesis that the variables have unit roots. To be sure, the variables are coordinated of request one i.e. I(1). Thusly, both the expanded Dickey Fuller and the Philip Perron test for stationary achieve a comparative conclusion with respect to the stationarity status of the variables. 
Table 1.3. Descriptive Statistics

\begin{tabular}{|c|c|c|c|c|c|}
\hline & Mean & Median & Maximum & Minimum & Std. Dev. \\
\hline TDT & 65 & 68 & 85 & 46 & 12.69537 \\
\hline TTR & 2155.604 & 493.6029 & 11116.85 & 10.5087 & 2981.197 \\
\hline TIT & 35 & 32 & 54 & 15 & 12.69537 \\
\hline FDI & 302713.3 & 86772.95 & 5028391 & 264.3 & 906621.4 \\
\hline INF & 23.08667 & 15.5 & 33.1 & 4.7 & 18.43776 \\
\hline OPN & 85.95867 & 72.75 & 111.2 & 28.5 & 48.2565 \\
\hline GINI & 43.953 & 46.4000 & 60.0000 & 16.96000 & 10.08277 \\
\hline
\end{tabular}

Source: Researcher's Compilation (2015).

The descriptive statistics is presented for the variables as shown in Table 1.3. As observed, TDT has a mean value of N65bn with a standard deviation of 12.695. Maximum and minimum values are N85bn and N46bn respectively. TTR has a mean value of $2155.604 \mathrm{bn}$ with a standard deviation of 2981.197. Maximum and minimum values are N11116.85bn and N10.5087bn respectively. TIT has a mean value of N35bn with a standard deviation of 12.695. Maximum and minimum values are N54bn and N15bn respectively.

FDI has a mean value of 302713.3bn with a standard deviation of 906621 . The Maximum and minimum values are 5028391 and 264.3 respectively. INF has a mean value of 15.5 with standard deviation of 18.437 . The Maximum and minimum values are 33 and 8.7 respectively. OPN has a mean value of 85.958 with a standard deviation of 201.2. The Maximum and minimum values are 111.2 and 28.5 respectively. GINI has a mean value of 43.953 with a standard deviation of 10.082 . The Maximum and minimum values are 60 and 16.9600 respectively. OPN has a mean value of 85.958 with a standard deviation of 201.2. The Maximum and minimum values are 111.2 and 28.5 respectively.

\subsection{Regression Analysis}

\subsubsection{Regression output}

Dependent Variable: D(GINI)

Method: Least Squares

Date: 09/13/15 Time: 22:55

Sample(adjusted): 19822014

Included observations: 33 after adjusting endpoints

\begin{tabular}{lllll}
\hline \hline Variable & Coefficient & Std. Error & t-Statistic & Prob. \\
\hline \hline C & -44.8081 & 1.19512 & 4.203124 & 0.0000 \\
D(TDT) & -0.29307 & 1.94409 & -1.66425 & 0.8812 \\
D(TTR) & -0.00022 & 0.00120 & 0.168302 & 0.9001 \\
D(TIT) & -0.32867 & 1.94579 & -0.69128 & 0.8679 \\
D(OPN) & -0.05972 & 0.0523 & -1.00361 & 0.2641 \\
D(FDI) & $-4.15 \mathrm{E}-07$ & $7.14 \mathrm{E}-07$ & -3.92043 & 0.0055 \\
D(INF) & 0.01912 & 0.06931 & 1.54841 & 0.5662 \\
GINIRESID01(-1) & -0.81471 & 0.12869 & -4.11012 & 0.0000 \\
\hline \hline R-squared & 0.635113 & Mean dependent var & 9.422841 \\
Adjusted R-squared & 0.533229 & S.D. dependent var & 35.56494 \\
S.E. of regression & 6.16212 & Akaike info criterion & 8.932208 \\
Sum squared resid & 9571.986 & Schwarz criterion & 9.249649 \\
Log likelihood & -140.3814 & F-statistic & 6.2269 \\
Durbin-Watson stat & 1.76981 & Prob(F-statistic) & 0.000000 \\
\hline \hline
\end{tabular}

Source: Researcher's computation (2015) 
The estimations from the regression result above showed the effect of tax revenue on income disparity as measured by the GINI coefficient. The $\mathrm{R}^{2}$ of the model is $63.5 \%$ with an adjusted $\mathrm{R}^{2}$ of $53.3 \%$. The F-stat is 6.226 ( $p$-value $=0.00$ ) is significant at $5 \%$ and suggest that the hypothesis which state that there is a significant linear relationship between the dependent and independent variables cannot be rejected. The $D$. W statistics of 1.8 reveals the absence of stochastic dependence in the model. Commenting on the performance of the structural coefficients, the coefficient and $p$-values of the three tax variants TDT, TTR and TIT are given as follows; -0.293 $\{0.8813\}, 0.0002\{0.9002\}$ and $-0.328\{0.867\}$ respectively. The estimates reveal that all tax variants do not have any significant impact on the GINI coefficient at $5 \%$ level. The error correction component $\{E C M(-1)\}$ is has expected negative sign $(-0.814)$ and significant at $5 \%(p=0.629)$. FDI, Openness and INF used as control variables are not significant

\section{Discussion of Findings}

Estimations show the effect of tax revenue on income disparity as measured by the GINI coefficient. Commenting on the performance of the structural coefficients, the coefficient and $p$ values of the three tax variants TDT, TTR and TIT are given as follows; $-0.293\{0.8813\}, 0.0002$ $\{0.9002\}$ and $-0.328\{0.867\}$ respectively. The estimates reveal that all tax variants do not have any significant impact on the GINI coefficient at $5 \%$ level and hence we fail to reject the hypothesis which states that Taxes have no significant positive effect on income inequality. The study finding is in tandem with Chu, Davoodi and Gupta (2000) but at variance with those of James and Robert (2007), Claus et al. (2012), Rodrigo and Ivanna (2010) and Weller and Rao (2008).

\section{Conclusion and Recommendations}

The study investigated the extent to which taxes have been able to address the issue of income inequality in Nigeria. it compliment more studies on the issue of taxation and income distribution but emphasising tax revenue from tax variants perspective which are direct tax; indirect tax and total tax revenue as compared to most studies which basically have used disaggregated data in evaluating income inequality. The paper concluded that all tax variants do not exert significant impact on income disparity as measured by GINI at $5 \%$ level. The result suggests the taxation as not be able to fulfil its role as a standard tool of income re-distribution in Nigeria. Premised on the conclusion the paper recommended that the there is the need for effective, and equitable utilization of tax revenue and this recommendation suffices because of the insignificant impact of taxes on the level of income inequality as measured by the Gini-coefficient. Thus, the study proposes that that there is the need to examine properly the distributional impact of the Nigerian tax system to (or "intending to") ensuring that taxes create a more income-inclusive society by bridging the gap between the poor people and the rich

\section{References}

Adejuwon, G. (2009). Analysis of taxation principles for Nigeria students. Agege, Lagos: Not by Power Nigeria Limited.

Akintoye, I.R., \& Tashie, G.A. (2013). The effect of tax compliance on economic growth and development in Nigeria, West Africa. British Journal of Arts and Social Science, 2 (2), 222- 231.

Anyanwu, J. C. (1997). Nigerian public finance. Onitsha: Joanne Educational Publishers.

Appah, E. (2004). Principles and practices of Nigeria taxation. Port Harcourt: Ezevin Mint Printers and Publishers.

Appah, E., \& Oyandonghan, J.K. (2011). The challenges of tax mobilisation and management in the Nigerian economy. Journal of Business Administration and Management, 6 (2), 128-136.

Anyuduba, J.O. (2000). Personal income taxation in Nigeria. Benin City: United Press.

Ariwodola, J.A. (2008). Personal taxation in Nigeria including capital gains tax (5 $5^{\text {the }}$ ). Festac Lagos: JAA Nigeria Limited.

Ayodele,O. (2006). Tax policy reforms in Nigeria, World Institute for Development Economic Research, Research paper No. 2006/03 
Azubuike, J.U.B. (2009). Challenges of tax authorizes, tax payers in the management of tax reform process. Nigerian Accountant, 42 (2), 36- 42.

Bhartia, H. L. (2009). Public finance (14 ${ }^{\text {th }}$ ed.). New Delhi: Vikas Publishing House PVT Ltd.

Chu, K., Davoodi, H., \& Gupta, S. (2000). Income distribution and tax and government social spending policies in developing countries. IMF Working Paper, 00/62 (Washington: International Monetary Fund).

Claus, I, Martinez-Vazquez, J., \& Vulovic, V. (2012). Government fiscal policies and redistribution in Asian Countries. Asian Development Bank Economic Working Paper.

Eiya, O. (2012). Taxation at a glance. Benin City: The Guide Press.

Ilaboya, O.J., \& Ohonba, N. (2012).Direct versus indirect taxation and income inequality. European Journal of Accounting and Finance Research, 1 (1), 1 -15.

Jhingan, M. L. (2004). Money, banking, international trade and public finance. New Delhi: Vrinda Publications.

Johanson, A., Heady, C., Arnold, J., Brys, B., \& Vartia, L. (2008). Tax and economic growth. OECD Working Paper, No 620. Retrieved from: www.OECD.org/eco/ working papers.

Kuznets, S. (1953). Economic growth and economic inequality. American Economic Review, 45 (2), 1-28.

Musgrave, R. A., \& Musgrave, P.B. (2004). Public finance in theory and practice. New Delhi, India: Tata McGraw Hill.

Naiyeju, J. K. (1996). Value added tax: The facts of a positive tax in Nigeria. Kupag Public Affairs.

Ndekwu, J. K. (1991). An analytical review of Nigeria's tax system and administration. Paper presented at a national workshop on tax structure and administration in Nigeria, Lagos, 15-17, May.

Odusola, A.E. (2006). Rekindling investment and economic development in Nigeria. NES selected paper for the 1998 annual conference.

Ogbonna, G. N., \& Appah, E. (2012). Impact of tax reforms and economic growth of Nigeria: A time series analysis. Current Research Journal of Social Sciences, 4 (1), 62-68.

Ola, C. S. (2001). Income tax law and practice in Nigeria( $5^{\text {th }}$ ed.). Ibadan: Dalag Prints and Park.

Oladiran, A. (2009). Resources taxation as a tool for development, I.E.I.R.2. Thomson Reuters (Legal) Limited and Contributors.

Osemeke, M. (2010). Practical approach to taxation and tax management. Benin City: Ethiope Publishing Corporation, Ring Road.

Saez, E. (2004). Direct or indirect tax instruments for redistribution: Short-run versus long-run. Journal of Public Economics, 58 (2), 503-518.

Weller, C.E., \& Rao, M. (2008). Can progressive taxation contribute to economic development? Political Economy Research Institute Working Paper 176

Worlu, C. N., \& Emeka, N. (2012). Tax revenue and economic development in Nigeria: A macro econometric approach. Academic Journal of Interdisciplinary Studies, 1 (2), 211-223. 


\section{Appendix}

\section{Regression Data}

\begin{tabular}{|c|c|c|c|c|c|c|c|}
\hline & $\begin{array}{c}\text { TDT } \\
\text { (Nmill) }\end{array}$ & $\begin{array}{c}\text { TTR } \\
\text { (Nmill) }\end{array}$ & $\begin{array}{c}\text { TIT } \\
\text { (Nmill) }\end{array}$ & GINI\% & $\begin{array}{c}\text { FDI } \\
\text { (Nmill) }\end{array}$ & OPN\% & INF(\%) \\
\hline 1981 & 10.6 & 14.9 & 4.3 & 20.4 & 334.7 & 48 & 21.4 \\
\hline 1982 & 6.6 & 11.4 & 4.8 & 23.82 & 290 & 38 & 7.2 \\
\hline 1983 & 8.76 & 13.83 & 5.07 & 27.14 & 264.3 & 27 & 23.2 \\
\hline 1984 & 6.92 & 11.83 & 4.91 & 30.43 & 360.3 & 24 & 40.7 \\
\hline 1985 & 9.21 & 15.07 & 5.86 & 33.67 & 646.1 & 26 & 4.7 \\
\hline 1986 & 7.01 & 13.01 & 6 & 40.17 & 735.8 & 24 & 5.4 \\
\hline 1987 & 14.83 & 21.75 & 6.92 & 40.17 & 2452.8 & 42 & 10.2 \\
\hline 1988 & 9.95 & 19.05 & 9.1 & 47.25 & 1718.2 & 35 & 46 \\
\hline 1989 & 14.03 & 25.93 & 11.9 & 47.25 & 10899.9 & 60 & 50.5 \\
\hline 1990 & 31.17 & 45.45 & 14.28 & 50.9 & 10436.1 & 53 & 7.5 \\
\hline 1991 & 43.89 & 61.13 & 17.24 & 48 & 12244.2 & 65 & 12.9 \\
\hline 1992 & 58.66 & 81.87 & 23.21 & 44.95 & 20512.7 & 61 & 44.5 \\
\hline 1993 & 70.61 & 102.52 & 31.91 & 51 & 67787 & 58 & 57.3 \\
\hline 1994 & 59.45 & 105.77 & 46.32 & 51 & 119391.6 & 42 & 57 \\
\hline 1995 & 69.12 & 145.41 & 76.29 & 51 & 122600.9 & 60 & 73.1 \\
\hline 1996 & 103.55 & 201.12 & 97.57 & 46.5 & 128331.9 & 58 & 29.1 \\
\hline 1997 & 100.32 & 206.32 & 106 & 50.6 & 152410.9 & 77 & 8.5 \\
\hline 1998 & 108.13 & 217.57 & 109.44 & 53 & 154190.4 & 66 & 10 \\
\hline 1999 & 218.53 & 353.53 & 135 & 55 & 157508.6 & 56 & 6.6 \\
\hline 2000 & 600.7 & 760.7 & 160 & 60 & 161441.6 & 71 & 6.9 \\
\hline 2001 & 738.7 & 1001.1 & 262.4 & 51.5 & 166631.6 & 82 & 18.9 \\
\hline 2002 & 512.22 & 802.22 & 290 & 49 & 179687.6 & 63 & 12.9 \\
\hline 2003 & 815.22 & 1147.12 & 331.9 & 43.7 & 249639.3 & 75 & 14 \\
\hline 2004 & 1338.54 & 1719.24 & 380.7 & 48.82 & 324129.3 & 48 & 17 \\
\hline 2005 & 2096.02 & 2521.52 & 425.5 & 44 & 482447.8 & 51 & 21 \\
\hline 2006 & 2319.95 & 2729.95 & 410 & 58 & 552498.6 & 65 & 21.7 \\
\hline 2007 & 1888.14 & 2442.14 & 554 & 45.2 & 586309.7 & 64 & 27.2 \\
\hline 2008 & 3285.23 & 3891.03 & 605.8 & 43.7 & 400147.1 & 65 & 22 \\
\hline 2009 & 1973.33 & 2739.23 & 765.9 & 46.3 & 358735.8 & 62 & 12.5 \\
\hline 2010 & 2726.73 & 3598.83 & 872.1 & 42.95 & 534589.6 & 43 & 12.4 \\
\hline 2011 & 3238.08 & 3796.761 & 558.68 & 43.9 & 582651.4 & 53 & 11.7 \\
\hline 2012 & 4289.9 & 5007.623 & 717.726 & 41.33 & 567823.8 & 44 & 13.7 \\
\hline 2013 & 3995.38 & 4805.64 & 810.283 & 48.8 & 581873.1 & 31 & 10.1 \\
\hline 2014 & 3900.65 & 4714.565 & 813.913 & 49 & 505482.2 & 37 & 9.5 \\
\hline & & & & & & & \\
\hline
\end{tabular}

Source: CBN, NBS and World Bank Data bank 